\title{
STUDIES ON GENETIC ARCHITECTURE THROUGH VARIABILITY PARAMETERS AND ASSOCIATION ANALYSIS IN COWPEA [VIGNA UNGUICULATA (L.) WALP.]
}

\author{
Mayuri SAHU \\ Department of Genetics and Plant Breeding, Indira Gandhi Krishi Vishwavidyalaya, \\ Raipur, Chhattisgarh-492 012, India
}

Keywords: Genetic variability, Association analysis, Cowpea

\begin{abstract}
Genetic architecture through variability parameters and association analysis for green forage yield and its characters in 78 germplasm lines including 3 checks (MFC-8-14, UPC-5286 and TSFC-12-15) was carried out during Rabi 2015-2016. All the fifteen studied characters exhibited existence of variability significantly. This indicated existence of sufficient variability among the genotypes for the mentioned characters and sufficient scope for development of new variety or genotypes. High genetic advances as percentage of mean were recorded for green forage yield ( $q /$ ha/day). High heritability estimates were recorded for 100-seed weight (g) and by green forage yield (q/ha). Correlation coefficient showed significant positive correlation with dependent character green forage yield with green forage yield per day at genotypic and phenotypic level. Maximum positive direct effect was obtained for green forage yield per day. These results indicate that green forage yield can be improved much better way by selection. Selection for these traits is likely to accumulate more additive genes leading to further improvement of performance of genotypes.
\end{abstract}

\section{Introduction}

Vigna unguiculata $(\mathrm{L}$.$) Walp 2 \mathrm{n}=22$, a member of fabaceae, is a crop grown throughout the tropics and the substropics covering Africa, Asia, South America, parts of Southern Europe and the United State (Steele 1976). Vavilov (1939) considered India as the main Centre of Origin. In India, it has been known since the Vedic times. The cowpea one of several species of the widely cultivated genus Vigna has been subdivided in five sub species, three cultivated, unguiculata, sesquipedalis and cylindrical and two wild, dekindtiana and mensenensis (Verdcourt 1970).

Cowpea, one of the most important legume crops is now gaining importance in the recent years due to its high food value, good fodder and used as an excellent green manure crop. Its grain contains on average 23-25\% protein and 50-70 \% starch (Vir and Singh 2014). Apart from this, cowpea forms excellent forage and it gives a heavy vegetative growth and covers the ground so well that it checks the soil erosion.

Sanjeev et al. (2015) reported that the fodder cowpea occupies 0.3 million hectares out of 0.65 -million-hectare area under different pulse and vegetable cowpea types. Like grain yield, fodder yield in cowpea is also a complex character. It depends on the expression of various independent characters. Therefore, selection on the basis of one or more characters may not necessarily lead to the improvement in forage yield. It is, therefore, essential to know the association of various quantitative as well as qualitative characters in order to initiate an effective selection programme aiming at the improvement of yield and quality of the dual type cowpea. With the popularization of improved varieties of cowpea, traditionally grown genotypes are

*E-mail: <mayuri.igkv@gmail.com>. 
declining, even though they have many genetically important diverse traits. To conserve these genotypes there is need to collect and maintain such genotypes with scientific approach to avoid loss of valuable genetically diverse population.

The genetic variability for quantitative characters is of great importance in selecting the desired genotypes for future breeding programme. Information on genetic variability among different characters are essential for any systematic breeding programme. According to Bhagwati Baranda (2017), genetic variability is essential to realize response to selection pressure as the estimates of genetic parameters of variation are specific for a particular population and the phenotypic expression of the different quality and quantitative characters may be altered by environmental stress that affect plant growth and development.

Genotypic and phenotypic coefficients of variation and heritability accompanied with genetic advance are very important parameters in improving traits (Denton and Nwangburuka 2011). Heritability of a character is important for the cowpea breeder because it provides him an idea of the extant of genetic control for the expression of a particular character (Chopra 2000). Thus, the present study was carried out to assess the variability with the help of genetic parameters like the coefficient of variability, heritability, genetic advance and association analysis.

\section{Materials and Methods}

The experiments comprised of RBD 78 germplasm lines including 3 checks (MFC-8-14, UPC-5286 and TSFC-12-15) with 3 replications were carried out during Rabi 2015-16 at Research cum Instructional Farm on Cowpea, Department of Genetics and Plant breeding, Indira Gandhi Krishi Vishwavidyalaya, Raipur, Chhattisgarh. The experimental site is located between $17^{\circ} 14^{\circ e} \mathrm{~N}$ and $24^{\circ} 45^{\mathrm{ec}} \mathrm{N}$ latitudes and $79^{\circ} 16^{\circ \mathrm{C}} \mathrm{E}$ and $84^{\circ} 15^{\mathrm{ce}} \mathrm{E}$ longitudes. Raipur is the capital of the Chhattisgarh state and lies at $21^{\circ} 16^{\circ \mathrm{Ce}}$ latitude and $81^{\circ} 36^{\circ \mathrm{e}} \mathrm{E}$ longitude with an altitude of 289.60 meters above mean sea level. The region receives 1200-1400 mm rainfall annually out of which about $8 \%$ is received during Rabi season. The maximum temperature was $43.1^{\circ} \mathrm{C}$ and minimum $27.8^{\circ} \mathrm{C}$ during the crop growth period. The rainfall received during December $(10.0 \mathrm{~mm})$, January $(2.0 \mathrm{~mm})$, February $(0.3 \mathrm{~mm})$, April (5.4.) was observed in growth period of experiment. All recommended production and protection practices were followed to raise a good crop. The estimates of PCV and GCV were classified low, moderate and high according to Sivasubramaniam and Madhavamenon (1973). The estimated heritability was classified as low, moderate and high according to Robinson (1966). The genetic advance as percentage of mean was estimated following the formula of Johnson et al. (1955). The genotypic and phenotypic correlation coefficients were estimated and measure of direct and indirect effects were carried out according to the method developed by Wright (1921). Data of 15 characters, namely were subjected to analysis to calculate means, minimum and maximum values, variances and standard errors (SE) through MS Excel Software.

\section{Results and Discussion}

Results presented in Table 1 showed that the phenotypic coefficient of variation was higher than the genotypic coefficient of variation. It indicates that apparent variation is due to genotypes and influence of environment also. The high phenotypic coefficient of variation and genotypic coefficient of variation were recorded for green forage yield ( $\mathrm{q} / \mathrm{ha} /$ day) followed by green forage yield ( $\mathrm{q} / \mathrm{ha})$, dry matter yield ( $\mathrm{q} / \mathrm{ha} /$ day), dry matter yield $(\mathrm{q} / \mathrm{ha})$ and leaf stem ratio. The GCV and PCV values indicated that lot of variability exists among the genotypic and phenotypic level and better chances of improvement is possible by selection (Vira and Singh 2014). These findings are in agreement with the findings of previous workers Nwosu et al. (2013) and Kharde et al. (2014). 
Heritability in broad sense indicates the percentage of transfers of traits from generation to next. Depending upon the heritability of the traits characters were categorized into heritable, medium heritable and low heritable traits. In the present investigation, an attempt was made to estimate the broad sense heritability for different characters. High heritability (>70\%) estimates were recorded for 100-seed weight $(\mathrm{g})$ followed by Green forage yield( $\mathrm{q} / \mathrm{ha})$, Plant height $(\mathrm{cm})$, Green forage yield (q/ha/day), dry matter yield ( $\mathrm{q} / \mathrm{ha}$ ), leaf stem ratio, day of $50 \%$ flowering, dry matter yield (q/ha/day), day to maturity, seed yield per plant $(\mathrm{g})$, leaf length $(\mathrm{cm})$, number of primary branches, leaf width $(\mathrm{cm})$ and Pod length $(\mathrm{cm})$. Number of locules per pod $(30-70 \%)$ indicated medium heritability. High heritability indicated that these characters were highly heritable and governed by additive gene effects (Nwosu et al. 2013). The phenotypic values could give a fairly good idea about their genetic material. The findings are inconformity to the findings of Bhadru and Navale (2012) and Kharde et al. (2014).

High genetic advance as percentage of mean was recorded for green forage yield ( $\mathrm{q} / \mathrm{ha} /$ day) followed by Green forage yield ( $\mathrm{q} / \mathrm{ha}$ ), dry matter yield ( $\mathrm{q} / \mathrm{ha} /$ day), dry matter yield ( $\mathrm{q} / \mathrm{ha}$ ), leaf stem ratio, seed yield per plant $(\mathrm{g})$, plant height $(\mathrm{cm}), 100$-seed weight $(\mathrm{g})$, number of primary branches, pod length $(\mathrm{cm})$, leaf width $(\mathrm{cm})$, days to $50 \%$ flowering, days to maturity, leaf length $(\mathrm{cm})$ and number of locules per pod. These finding indicated that green forage yield can be improved much better way by selection. Kharde et al. (2014) reported that genetic advance over mean estimates was high for pod length, plant height. Selection for these traits is likely to accumulate more additive genes leading to further improvement of performance of genotypes.

The phenotypic, genotypic coefficients of correlation were determined among yield components in all possible character combination and are presented in Table 2. For most of the characters genotypic correlation was higher in magnitude than the phenotypic correlation.

Seed yield per plant exhibited positive significant correlation with green forage yield per day followed by seed yield and leaf stem ratio whereas negative significant correlation with leaf length at genotypic and phenotypic level, respectively.

Green forage yield per day leaf length showed positive significant correlation with dry matter yield per day, dry matter yield and green forage yield at genotypic and phenotypic level, respectively.

Dry matter yield showed positive significant correlation with dry matter yield per day and green forage yield at genotypic and phenotypic level, respectively. Dry matter yield per day exhibited positive significant correlation with green forage yield at genotypic and phenotypic level, respectively. The present investigation showed significant positive correlation with depending character green forage yield with green forage yield per day, dry matter yield per day, dry matter yield, number of primary branches and number of locules per pod at genotypic and phenotypic level. Yield is a complex character, influenced by environmental fluctuations. Therefore, direct selection for yield as such will not be reliable and fruitful. Hence, selection criteria based on yield components would be helpful to select suitable plant types. The knowledge of inter-relationship between yield components and the relative weightage should be given to different yield components to obtain maximum gain. Thus, constructions of selection indices will be helpful to discriminate desirable genotypes on the basis of their phenotypic performance (Vir $e t$ al. 2014 and Bhagwati Baranda 2017). This provides experimental frame work for doing a straight forward analysis of variances, other necessary calculations and identifications of crosses likely to produce viable hybrids and crosses for pure line breeding. 


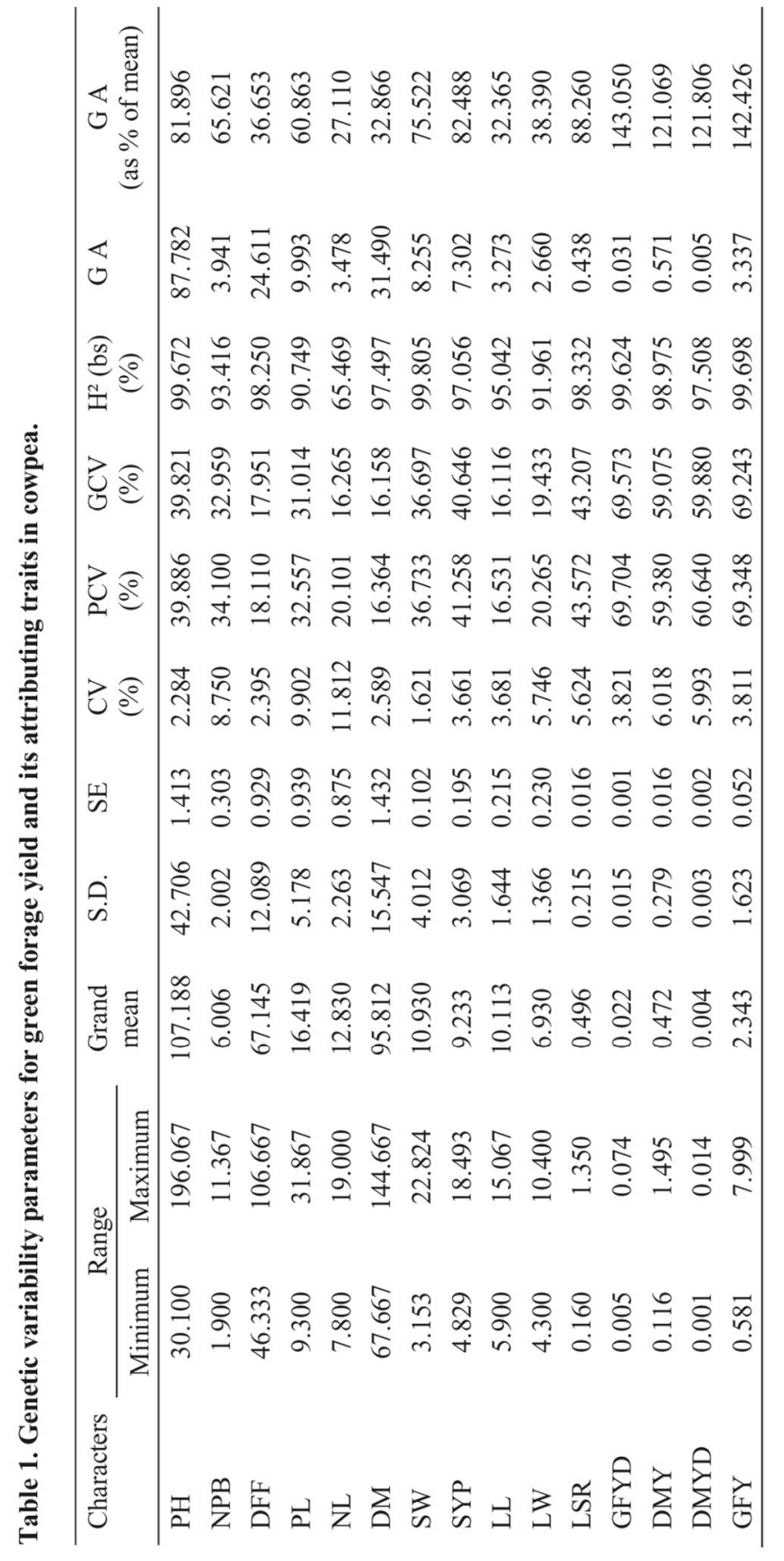




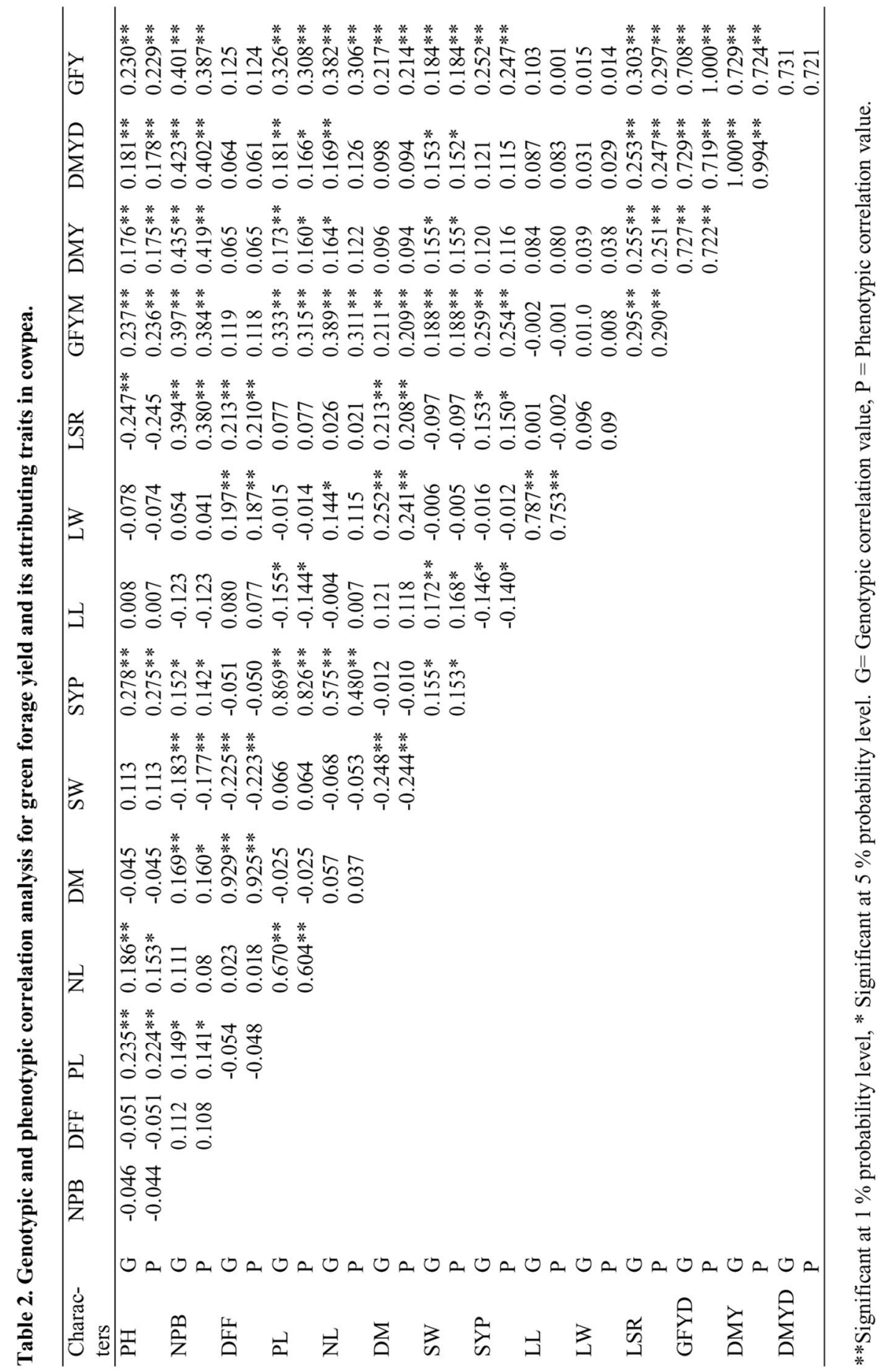




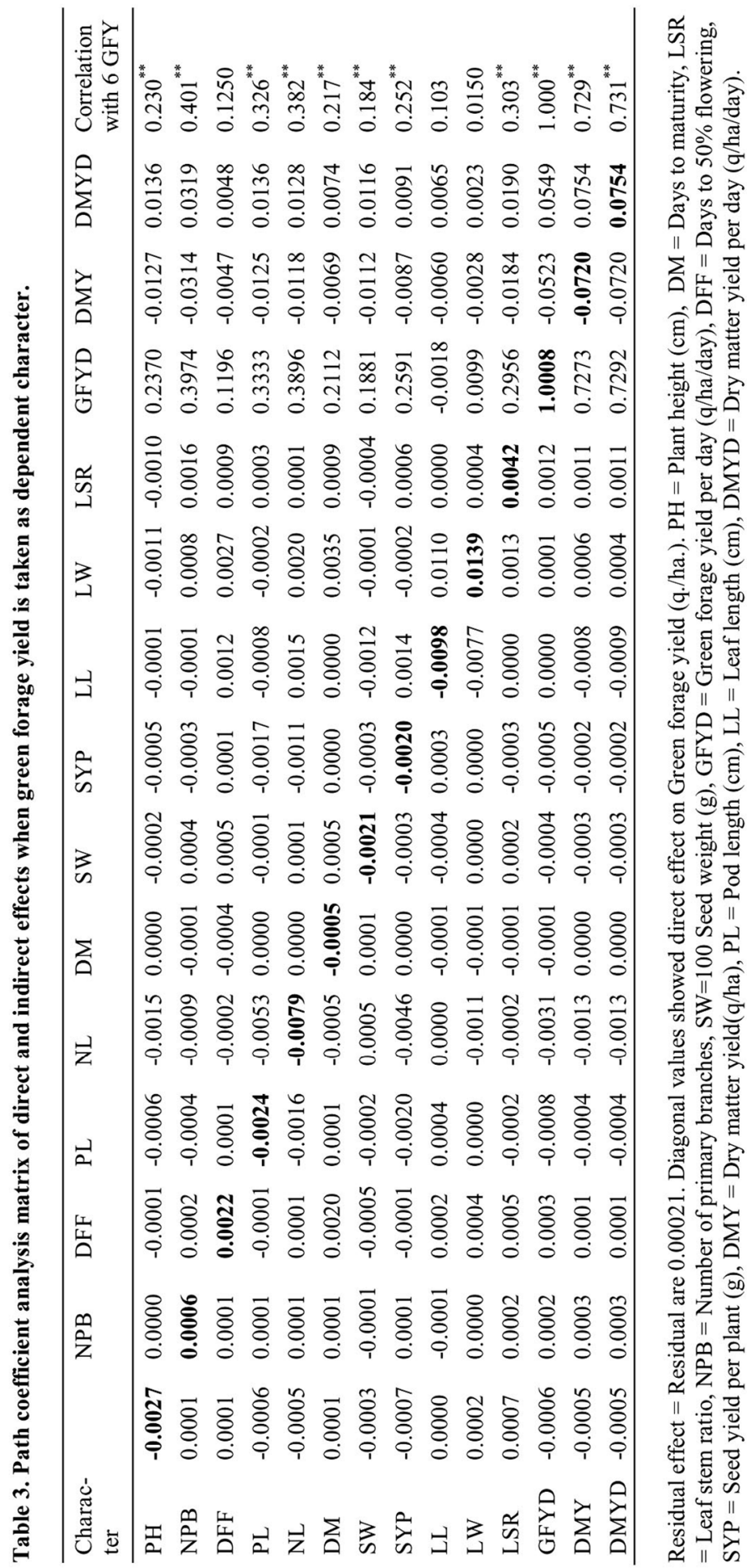


Path coefficient analysis partitioned the observed genotypic correlation coefficient between yield and its components into direct and indirect effects. The genotypic path coefficient (direct and indirect effects via other characters) was as follows:

In Table 3, path analysis when green forage yield ( $\mathrm{q} / \mathrm{ha}$.) was considered as dependent trait. Maximum positive direct effect were obtained for green forage yield per day followed by dry matter yield per day, leaf width and leaf stem ratio, whereas negative direct effect were obtained via, dry matter yield followed by leaf length, number of locules per pod and plant height.

Seed yield per plant indicated positive indirect effect on green forage yield per day followed by dry matter yield per day and leaf length whereas positive significant correlation was with green forage yield.

Green forage yield per day exhibited positive indirect effect on dry matter yield per day followed by leaf stem ratio and day to 50\% flowering whereas positive significant correlation with green forage yield. Dry matter yield exhibited positive indirect effect on green forage yield per day followed by dry matter yield per day and leaf stem ratio and positive significant correlation with green forage yield.

Dry matter yield per day exhibited positive indirect effect on green forage yield per day followed by leaf stem ratio and leaf width and positive significant correlation with green forage yield (0.7310), Bhardu and Navale (2011), Pratishtha et al. (2018) also carried out research in this line with Vigna unguiculata L. Walp. In path analysis when green forage yield was considered as dependent trait, maximum positive direct effect was obtained for dry matter yield per day followed by green forage yield per day, leaf width and leaf stem ratio whereas negative direct effect were obtained via, dry matter yield followed by leaf length, number of locules per pod and plant height.

\section{References}

Bhadru D and Navale PA 2012. Genetic variability parameters in $\mathrm{F}_{2}$ and $\mathrm{F}_{3}$ populations of Cowpea (Vigna unguiculata (L.) Walp.). Legume Res. 35(1): 75-77.

Chopra VL 2000. Plant Breeding - Theory and Practice 2nd Ed. Oxford and IBH Pub. Co. Pvt. Ltd. New Delhi p.10.

Denton OA and Nwangburuka CC 2011. Heritability, genetic advance and character association in six related characters of solanum anguivi. Asian J. of Agri. Res. 5: 201-207.

Johnson HW, Robinson HF and Comstock RE 1955. Estimation of genetic and environmental variability in soybeans. Agron. J. 47: 314-318.

Kharde RP, Kale VS and Bhogave AF 2014. Genetic variability studies in Cowpea. Bionfolet 11(1A): 113118.

Nwosu DJ, Olatunbosun BD and Adetiloye IS 2013. Genetic variability, heritability and genetic advance in cowpea genotype in two agro-ecological environments. Greener J. Bio. Sci. 3(5): 202-207.

Pratishtha D, Sharma MK, Soni AK, Ayush D and Singh P 2018. Character association and path coefficient analysis in vegetable cowpea (Vigna unguiculate (L.) Walp), J. Pharmaco. Phytochem. 7(1): 2289-2293

Robinson HF 1966. Quantitative genetics in relation to breeding on centennial of Mendelism. Indian J. Genet. 26(A): 171-187.

Sanjeev BG, Krishnappa MR, Shekara BG and Rudraswamy DP 2015. Gene action and combining ability for fodder yield and its contributing traits in fodder cowpea (Vigna unguiculata(L.) Walp.). Forage Res. 40(4): 218-221.

Sivasubramanian J and Madhavamenon P 1973. Genotypic and phenotypic variability in Rice. Madras Agricul. J. 12: 15-16.

Steele WM 1976. Cowpeas in: Evolution of crop plants (Simmonds, N.W.) Ed. Longman, London. pp. 183185.

Vavilov NI 1939. Chromosome atlas of cultivated plants. George Allen Unwin Ltd., London. 
Verdcourt B 1970. Studies in the leguminosae-papilionoideae for the flora of tropical east Africa. Kew Bulletin 24: 507.

Vir O and Singh AK 2014. Genetic variability and inter-characters associations studies in the germplasm of Cowpea [Vigna unguiculata (L.) Walp] in fragile climate of western Rajasthan, India. Legume Res. 37(2): 126-132.

Wright S 1921. Correlation of Causation. J. Agric. Res. 20: 257-287.

(Manuscript received on 28 July, 2018; revised on 27 October, 2020) 